\title{
Późnoglacjalna depozycja osadów dolinek wschodnich stoków Buślarskich Gór (Pojezierze Zachodniopomorskie)
}

\author{
Buślarskie Hills (Zachodniopomorskie Lakeland) east slopes valleys late glacial sediments \\ deposition
}

\author{
Renata Paluszkiewicz \\ Instytut Geoekologii i Geoinformacji, Uniwersytet im. Adama Mickiewicza w Poznaniu, reniach@amu.edu.pl
}

\begin{abstract}
Zarys treści: Celem artykułu jest charakterystyka późnoglacjalnych osadów wykształconych na wschodnich stokach Buślarskich Gór (Pojezierze Zachodniopomorskie). Szczegółowym badaniom poddane zostały osady znajdujące się w obrębie dwóch suchych dolinek erozyjno-denudacyjnych. Analizowane osady dolinek erozyjno-denudacyjnych są reprezentowane przez frakcje piasków średnio- i drobnoziarnistych o słabym stopniu wysortowania. W omawianych przypadkach za główny proces kształtujący dolinki uznać należy spłukiwanie, które współcześnie może być warunkowane gospodarczą działalnością człowieka.
\end{abstract}

Słowa kluczowe: dolinki erozyjno-denudacyjne, osady stokowe, procesy stokowe, Pojezierze Zachodniopomorskie

\begin{abstract}
The objective of this article is to characterize the late glacial deposits built on the east slopes of Buślarskie Hills (Zachodniopomorskie Lakeland). Deposits built in two dry erosion and denudation valleys underwent detailed research. The analysed slope deposits are represented by poorly graded fine- and medium-grained sand. In the cases discussed, ground wash should be considered the main valley-shaping process; at present, it may be conditioned by the economic activity of man.
\end{abstract}

Key words: erosion and denudation valleys, slope deposits, slope processes, Zachodniopomorskie Lakeland

\section{Wprowadzenie}

Na obszarze całego Niżu Polskiego po wycofaniu się lądolodu zlodowacenia wisły rozwój form wklęsłych warunkowany był przede wszystkim zmianami klimatycznymi i dominującymi wówczas procesami denudacyjnymi, z których do najważniejszych zaliczyć należy: spłukiwanie, spełzywanie i soliflukcję (Churska 1965, Klatkowa 1965, Rotnicki 1966, Kostrzewski 1971, Kozarski 1971). Etapy rozwoju suchych form wklęsłych są bardzo często traktowane jako źródło informacji paleogeograficznej, dotyczące zmian zachodzących u schyłku zlodowacenia wisły i w holocenie (m.in. Jersak, Śnieszko 1987, Kołodyńska-Gawrysiak 2004). Pierwotne formy glacjalne i peryglacjalne charakterystyczne dla obszaru młodoglacjalnego Pojezierza Zachodniopomorskiego są obecnie modyfikowane przez procesy denudacyjne oraz spłukiwanie. Modelują one w znaczący sposób rzeźbę stref krawędziowych wysoczyzn morenowych, rynien jeziornych i powierzchni sandrowych. W wyniku działania m.in. procesów spłukiwania $\mathrm{w}$ strefach krawędziowych obszaru młodoglacjalnego powstaje szereg form wklęsłych, takich jak: niecki denudacyjne, dolinki erozyjno-denudacyjne i wąwozy. Choć uznaje się generalnie, że formy te mają późnoglacjalną genezę, to niewątpliwie ich przekształcenie następowało $\mathrm{w}$ efekcie działania procesów spłukiwania i erozji na przełomie plejstocenu i holocenu (m.in. Majewski 2008, Paluszkiewicz 2011). Zapis rozwoju form erozyjnych znajduje się w osadach zdeponowanych głównie pod postacią pokryw w ich dolnym odcinku nazywanym za Teisseyrem (1994) strefą depozycyjną. U wylotu badanych dolinek erozyjno-denudacyj- 


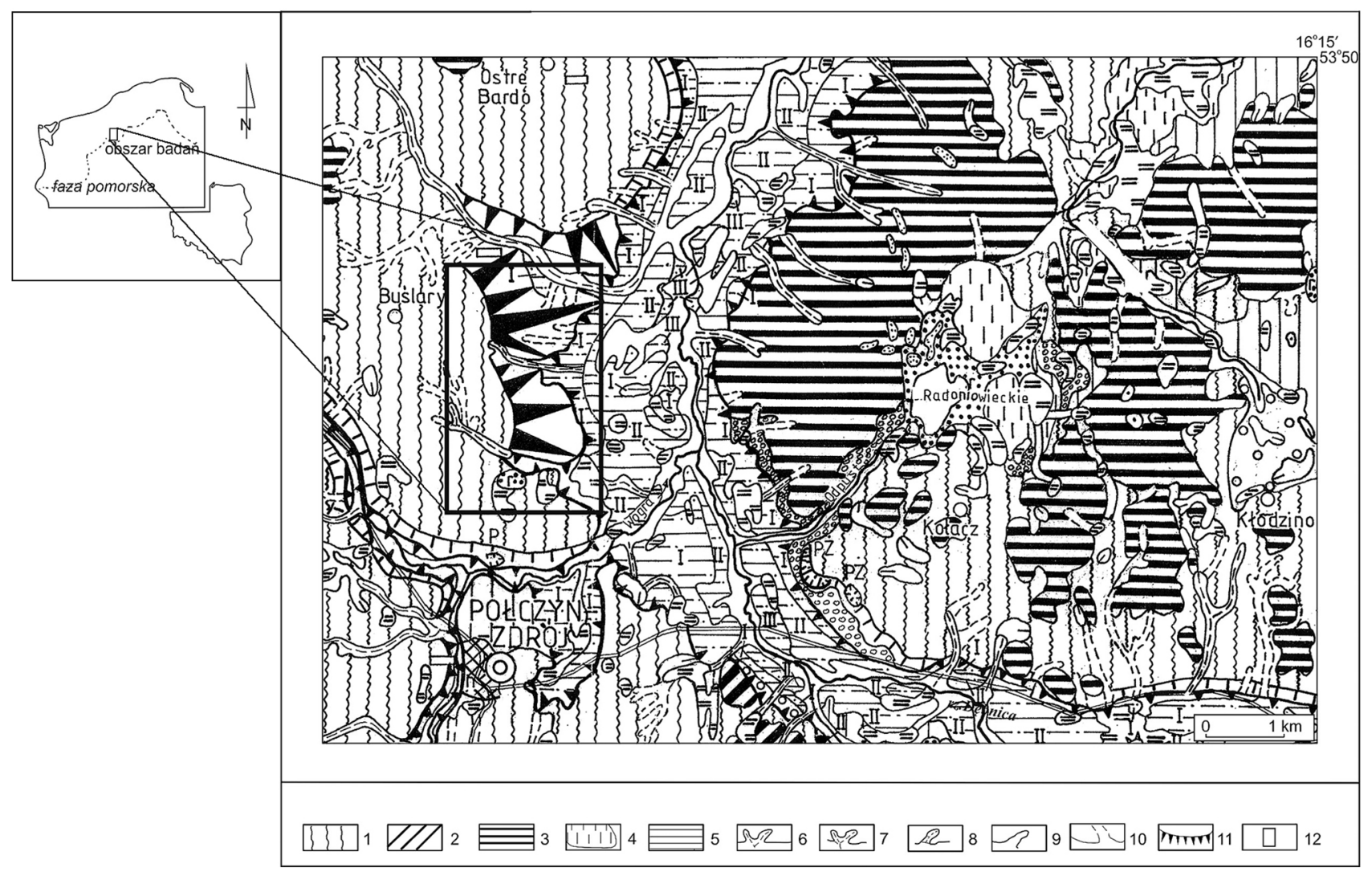

Ryc. 1. Obszar badań na tle szkicu geomorfologicznego (wg Dobrackiej, 2009)

1 - wysoczyzny morenowe faliste, 2 - moreny czołowe akumulacyjne, 3 - kemy, plateau kemowe, 4 - zagłębienia końcowe (wytopiskowe), 5 - terasy rzeczne nadzalewowe 2,0-5,0 m nad poziomem rzeki, 6 - dolinki, parowy, młode rozcięcia erozyjne, nierozdzielne, 7 - dolinki zawieszone, 8 - dolinki zawieszone i ponownie rozcięte, 9 - suche doliny, 10 - dolinki denudacyjne, 11 - długie stoki, 12 - obszar badań

Fig. 1. Location of study area against geomorphological sketch (after Dobracka 2009)

1 - undulating moraines plateau, 2 - accumulation terminal moraines, 3 - kame, kame plateau, 4 - terminal basins (kettle holes), 5 - river overflow terraces $2.0-5.0 \mathrm{~m}$ over river level, 6 - valleys, gullies, young erosional ravines, inseparable, 7 - perched valleys, 8 - hanging and again dissected valleys, 9 - dry valleys, 10 - denudation valleys, 11 - long slopes, 12 - study area

nych nie spotyka się wyraźnie wykształconych stożków napływowych, a materiał zdeponowany jest pod postacią pokryw deluwialnych (Paluszkiewicz 2008, 2013). Osady występujące w ujściowych odcinkach dolinek stanowią zapis przebiegu typu i intensywności procesów denudacyjnych odpowiedzialnych za ich utworzenie. Formy te nie są odwadniane przez ciek stały, zaś przepływ epizodyczny pojawiać się może podczas zjawisk ekstremalnych (intensywne opady deszczu).

\section{Cel, zakres i metody badań}

Celem badań było rozpoznanie cech osadów wypełniających dolinki w rejonie miejscowości Buślarki oraz określenie procesów denudacyjnych zachodzących na obszarze ich zlewni. Podjęto również próbę ustalenia tempa procesów denudacyjnych na podstawie miąższości pokryw deluwialnych.

W celu realizacji podjętego problemu badawczego przeprowadzono badania terenowe i laboratoryjne w obrębie wytypowanych stanowisk $\mathrm{z}$ zastosowaniem metod geologicznych i geomorfologicznych. Wyniki badań tere- nowych i laboratoryjnych opracowano kameralnie. Prace terenowe obejmowały:

- pomiary tachymetryczne dolinek erozyjno-denudacyjnych przy użyciu urządzeń GPS (SR530-RT Leica) oraz teodolitu Elta (model R55w),

- szczegółowe kartowanie litologiczne osadów form (sondowania ręczne do maksymalnej głębokości 5,5 m, wkopy oraz odsłonięcia o głębokości do $4 \mathrm{~m}$ ),

- pobór próbek osadów do dalszych analiz laboratoryjnych.

W ramach analiz laboratoryjnych i kameralnych:

- wykonano analizę składu mechanicznego osadów metodą areometryczno-sitową Cassagrande'a w modyfikacji Prószyńskiego (Racinowski 1973, Dzięciołowski 1980),

- określono zawartość węglanu wapnia za pomocą aparatu Scheiblera (Dzięciołowski 1980, Bednarek i in. 2004),

- przeprowadzono analizę stopnia obróbki ziarn kwarcu metodą graniformametrii mechanicznej Krygowskiego (1964) dla frakcji 1,4-1,0 mm i 1,0-0,8 mm.

Charakterystykę granulometryczną analizowanych osadów oparto na podziale Państwowego Instytutu Geo- 
logicznego (Instrukcja... 2004), zaś wskaźniki uziarnienia obliczono metodą Folka i Warda (1956), wykorzystując program Gradistat (Blott, Pye 2001).

Wykonano m.in. krzywe częstości, które obrazują udział ziaren o różnej średnicy w badanym osadzie, a ich przebieg pokazuje, czy osady są jedno- czy wielomodalne oraz w jakich przedziałach frakcyjnych występują dane mody (Mycielska-Dowgiałło 1992).

\section{Położenie, budowa geologiczna i morfologia obszaru badań}

Obszar badań położony jest w obrębie Wysoczyzny Łobeskiej, która należy do Pojezierza Zachodniopomorskiego (Kondracki 1998) i znajduje się w strefie marginalnej fazy pomorskiej zlodowacenia wisły. Osady czwartorzędowe Pojezierza Zachodniopomorskiego mają zróżnicowaną miąższość - od 15 m w strefach spiętrzeń glacitektonicznych koło Kołacza do 214 m w okolicy Kiełpina, gdzie tworzą morenę czołową.

Badania prowadzono na obszarze zlewni rzeki Dębnicy, w jej środkowym biegu. Do analizy późnoglacjalnych osadów wybrano stok o ekspozycji wschodniej. Teren badań od wschodu graniczy z plateau kemowym Skowrończych Gór i rozdzielony jest środkowym odcinkiem doliny Dębnicy o genezie fluwioglacjalnej. Kemy zbudowane są z piasków różnoziarnistych $\mathrm{z}$ przewarstwieniami żwirów i mułków, natomiast obszar wysoczyzny more- nowej tworzą piaski i żwiry z domieszką głazów wodnolodowcowych oraz piaski pyłowato-żwirowate lodowcowe. W północnej części strefy krawędziowej dolinki wcięte są w osady lodowcowych piasków pyłowato-żwirowych. Osady te zalegają na glinach moreny dennej, wykazując zróżnicowaną miąższość (maksymalnie do $5 \mathrm{~m}$ ). Tylko ujściowe części dolinek wcięte są w osady wodnolodowcowe (piaski i żwiry). Osady fluwioglacjalne, piaski i żwiry z domieszką głazów, stanowią dominujący typ osadów w obrębie środkowej i południowej części strefy krawędziowej (Dobracka 2009).

Krawędź wysoczyznowa w okolicach Buślarek wykazuje kierunek NE-SW. Jest ona rozczłonkowana przez liczne suche dolinki erozyjno-denudacyjne o zróżnicowanych długościach i głębokościach wcięcia koryta. Szczegółowa analiza geomorfologiczna obszaru badań była przedmiotem wcześniejszych opracowań Paluszkiewicz (2011) oraz Mazurek i Paluszkiewicz (2013). Do badań wytypowano dwie dolinki erozyjno-denudacyjne (A 5347'50.57" $\varphi \mathrm{N} ; 1^{\circ} 6^{\circ} 6^{\prime} 49.71^{\prime \prime} \lambda \mathrm{E} ; \mathrm{B}-5^{\circ} 47^{\prime} 57.33^{\prime \prime} \varphi$ $\left.\mathrm{N} ; 16^{\circ} 6^{\prime} 51.82^{\prime \prime} \lambda \mathrm{E}\right)$. Są one zlokalizowane w obrębie zachodniej części krawędzi wysoczyzny (ryc. 1).

\section{Charakterystyka morfometryczna dolinek erozyjno-denudacyjnych}

Dolinki erozyjno-denudacyjne zachodniej części krawędzi są formami o długości dna do 100 m. Różnica wy-
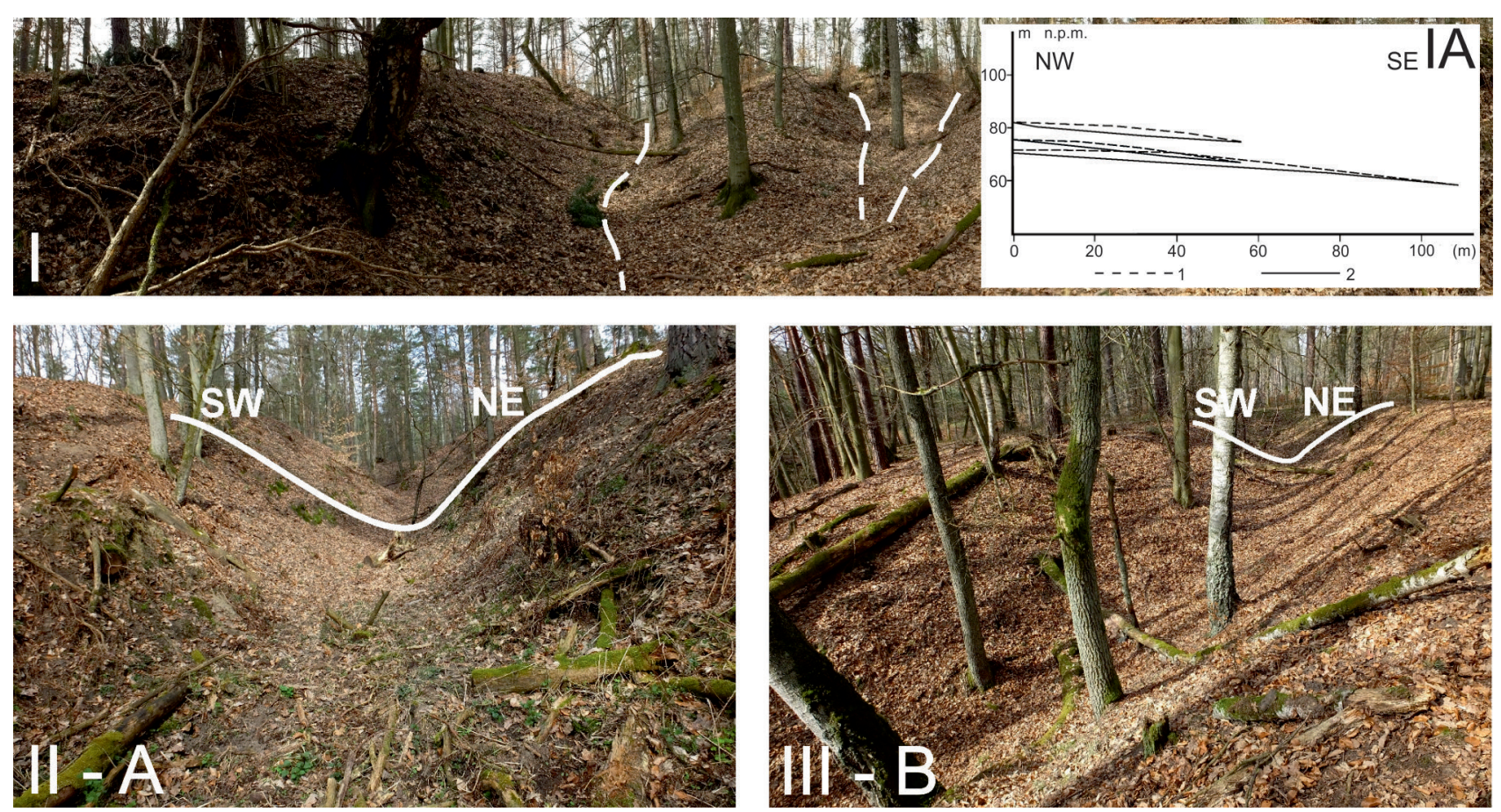

Ryc. 2. Dolinki erozyjno-denudacyjne

I - wschodnia część stoku Buślarskich Gór, II-A - dolinka A, III-B - dolinka B, Ia - Przykładowe profile podłużne dolinek zachodniej części strefy krawędziowej Buślarki

1 - powierzchnia pierwotna stoku, 2 - dno dolinki

Fig. 2. Erosion and denudation valleys

I - eastern part of Buślarskie Hills slope, II-A - valley A, III-B - valley B, Ia - Examples of longitudinal profiles of valleys in the western part of the edge zone of Buślarka

1 - slope primary surface, 2 - valley floor 
sokości pomiędzy górnym a dolnym odcinkiem dolinki A wynosi $14 \mathrm{~m}$, a w przypadku dolinki B $16 \mathrm{~m}$. Ich profile podłużne mają orientację NW-SE i wykazują nachylenie około $6^{\circ}$. Profile poprzeczne obu analizowanych form cechuje zróżnicowane nachylenie - od $13,5^{\circ} \mathrm{NE}$ do ponad $26^{\circ} \mathrm{SW}$. Największe głębokości wcięcia dolinek do $4 \mathrm{~m}$ zarejestrowano w ich środkowej części (ryc. 2). W kierunku wylotu dolinki wypłycają się i głębokość ich wcięcia w dolnej części wynosi około $1 \mathrm{~m}$.

Zasadnicze różnice w analizowanych formach dotyczą jednak powierzchni zlewni i kubatury dolinek. Po- wierzchnia zlewni dolinki A wynosi 2,82 ha, zaś jej kubatura to $2931,8 \mathrm{~m}^{3}$. W przypadku dolinki B sa to wartości odpowiednio 0,98 ha i $1222,4 \mathrm{~m}^{3}$. Zwrócono uwagę na całkowite rozcięcie powierzchni pierwotnej zbocza do podstawy stoku, co widoczne jest na profilach morfologicznych (ryc. 2).

\section{Wykształcenie osadów denudacyjnych}

Osady denudacyjne w obrębie badanych suchych dolinek erozyjno-denudacyjnych są głównie reprezentowane
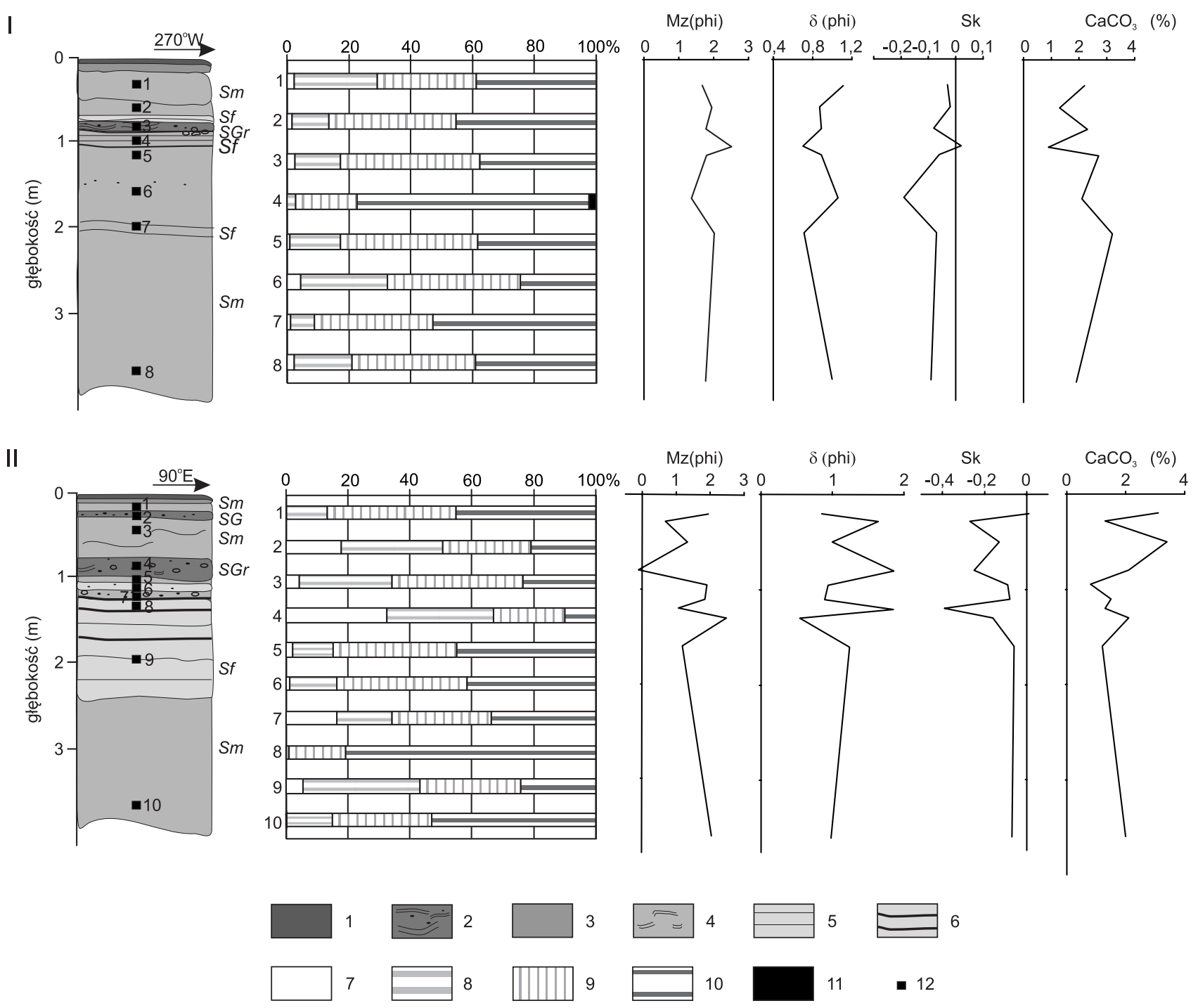

Ryc. 3. Profile litofacjalne oraz procentowa zawartość frakcji podstawowych w osadzie, wartości wskaźników uziarnienia i zawartość $\mathrm{CaCO}_{3}$

I - część górna dolinki A, II - część dolna dolinki A

1 - humus, 2 - piaski grubo- i średnioziarniste ze żwirem warstwowane przekątnie rynnowo ( $S G t), 3$ - piaski średnio- i drobnoziarniste, ciemne, masywne $(S m), 4$ - piaski średnio- i drobnoziarniste, jasne, laminowane przekątnie riplemarkowo $(S r), 5$ - piaski drobnoziarniste, laminowane smużyście $(S f), 6$ - wytrącenia żelaza, $7-<2 \mathrm{~mm}, 8-2-0,5 \mathrm{~mm}, 9-0,5-0,25 \mathrm{~mm}, 10-0,25-0,063$, $11-0,063-0,002 \mathrm{~mm}, 12$ - miejsce poboru próbek

Fig. 3. Litofacial profiles and percentage contents of basic fractions, grain-size distribution indexes and $\mathrm{CaCO}_{3}$ contents I - upper part of valley A, II - lower part of valley A

1 - humus, 2 - coarse- and medium-grained sands with gravel of trough cross- bedding $(S G t), 3$ - medium- and fine-gained sands, dark, massive $(S m), 4$ - medium- and fine-grained sands, light, with riplemark cross- lamination $(S r), 5$ - fine-grained sands, with flaser lamination $(S f), 6-$ ferrous precipitations, $7-<2 \mathrm{~mm}, 8-2-0,5 \mathrm{~mm}, 9-0,5-0,25 \mathrm{~mm}, 10-0,25-0,063 \mathrm{~mm}, 11-0,063-0,002$ $\mathrm{mm}, 12$ - sampling place 
przez piaski średnio- i drobnoziarniste. Wykształcenie litofacjalne osadów rozpoznane zostało we wkopach wykonanych w górnej i dolnej części dna dolinek (ryc. 3, 4).

W górnej części stoku, w podłożu serii deluwialnej, występują osady fluwioglacjalne, zwłaszcza piaski drobno- i średnioziarniste charakteryzujące się umiarkowanym stopniem wysortowania. Miąższość serii wynosiła 2,6 m. W stropowych częściach tej serii na głębokości $0,8 \mathrm{~m}$ występuje osad grubszy reprezentowany przez frakcję piasków gruboziarnistych, żwirów i głazów. Ich ułożenie sugeruje, że ukształtowana została tu warstwa bruku erozyjnego ograniczającego dalszy rozwój procesów denudacyjnych. Odsłonięcie w dnie dolinek osadów o większej odporności może ograniczyć jej pogłębianie i dalszy rozwój. Na głębokości $0,3 \mathrm{~m}$ zaobserwowano serię piasków średnio- i drobnoziarnistych o umiarkowanym stopniu wysortowania. Osady te charakteryzują się laminacją riplemarkową, co wskazuje na udział wód płynących w ich depozycji. Seria deluwiów reprezentowana jest przez piaski średnio- i drobnoziarniste o umiarkowanym i słabym stopniu wysortowaniu $(\delta=0,88-1,13$ phi) oraz ujemnych wartościach skośności. Ujemne wartości skośności świadczą o wzbogaceniu we frakcje grubsze. Miejscami, w dolnej części warstwy deluwiów, wykazują laminację smużystą (f) (Miall 1977, Zieliński 1995, Zieliński, Pisarska-Jamroży 2012), natomiast część górna ma strukturę masywną. W górnych częściach dolinek seria deluwialna osiąga $0,6 \mathrm{~m}$ miąższości w przypadku dolinki A i 0,4 $\mathrm{m}$ w przypadku dolinki B.

W ujściowych częściach dolinek podłoże dla serii deluwialnych stanowią również piaski fluwioglacjalne reprezentowane przez piaski średnio- i drobnoziarniste o łącznej miąższości około $3,5 \mathrm{~m}$. Seria ta cechuje się słabym i umiarkowanym stopniem wysortowania, a ujemne wartości skośności świadczą o wzbogaceniu we frakcje grubsze. Na głębokości $0,7 \mathrm{~m}$ występują osady gruboziarniste (piaski gruboziarniste ze znacznym udziałem żwiru) wypełniające rynnę erozyjną. Prawdopodobnie osady te związane są z funkcjonowaniem epizodycznego odpływu o charakterze linijnym. Drobne ziarna zostały wymyte i odprowadzone z osadu. Osady charakteryzuje słaby stopień wysortowania i ujemne wartości skośności. Osady te są warstwowane - przekątnie rynnowo $(S G t)$. Całość serii leżącej powyżej stanowi osad deluwialny reprezentowany przez piasek średnioziarnisty o słabym i umiarkowanym stopniu wysortowania o miąższości $0,7 \mathrm{~m}$. W osadzie tym, na głębokości około $0,3 \mathrm{~m}$, stwierdzono przewarstwienie piasku gruboziarnistego o słabym stopniu wysortowania. Przewarstwienie to może stanowić pozostałość po niewielki, spływie o charakterze bruzdowym $\mathrm{i}$ interpretowane jest jako osad proluwialny. Osady frakcji żwirowej i gruboziarnistej spotykane m.in. w deluwiach neoholoceńskich na obszarze Wyżyny Łódzkiej przez Twardego (2000) czy Stochlaka (1978) również interpre-
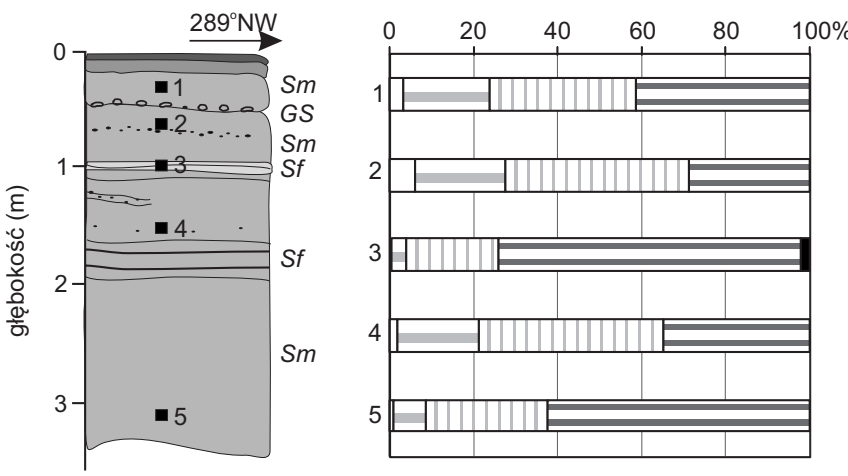

II

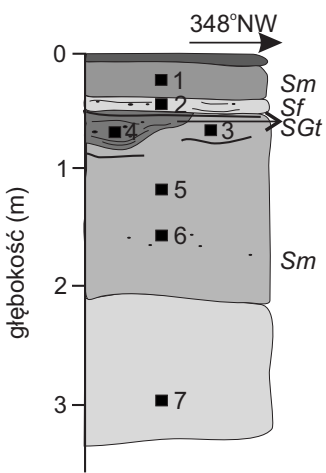

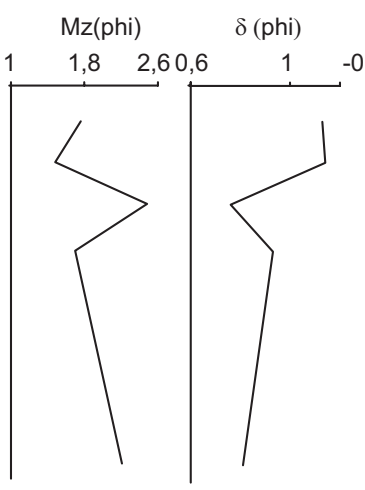

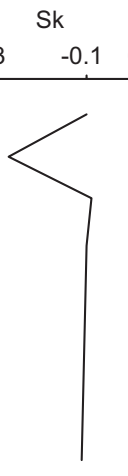

$\mathrm{CaCO}_{3}(\%)$

$0,5 \quad 1,5 \quad 2,5$
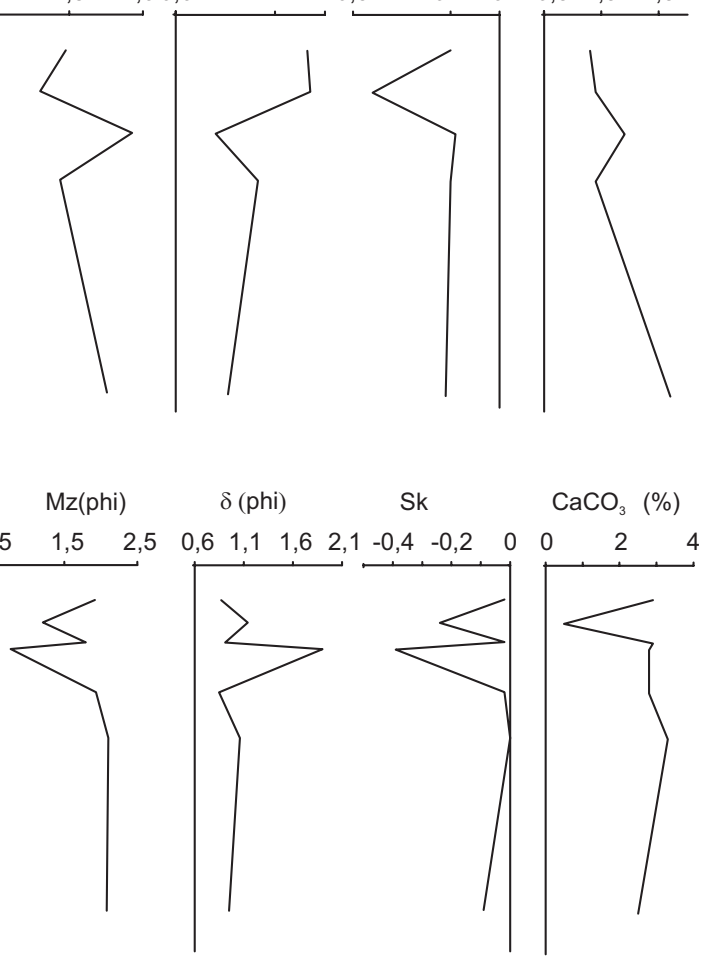

Ryc. 4. Profile litofacjalne oraz procentowa zawartość frakcji podstawowych w osadzie, wartości wskaźników uziarnienia i zawartość $\mathrm{CaCO}_{3}$

I - część górna dolinki B, II - część dolna dolinki B, objaśnienia jak na rycinie 3

Fig. 4. Litofacial profiles and percentage contents of basic fractions, grain-size distribution indexes and $\mathrm{CaCO}_{3}$ contents I - upper part of valley B, II - lower part of valley B, symbols as in Fig. 3 

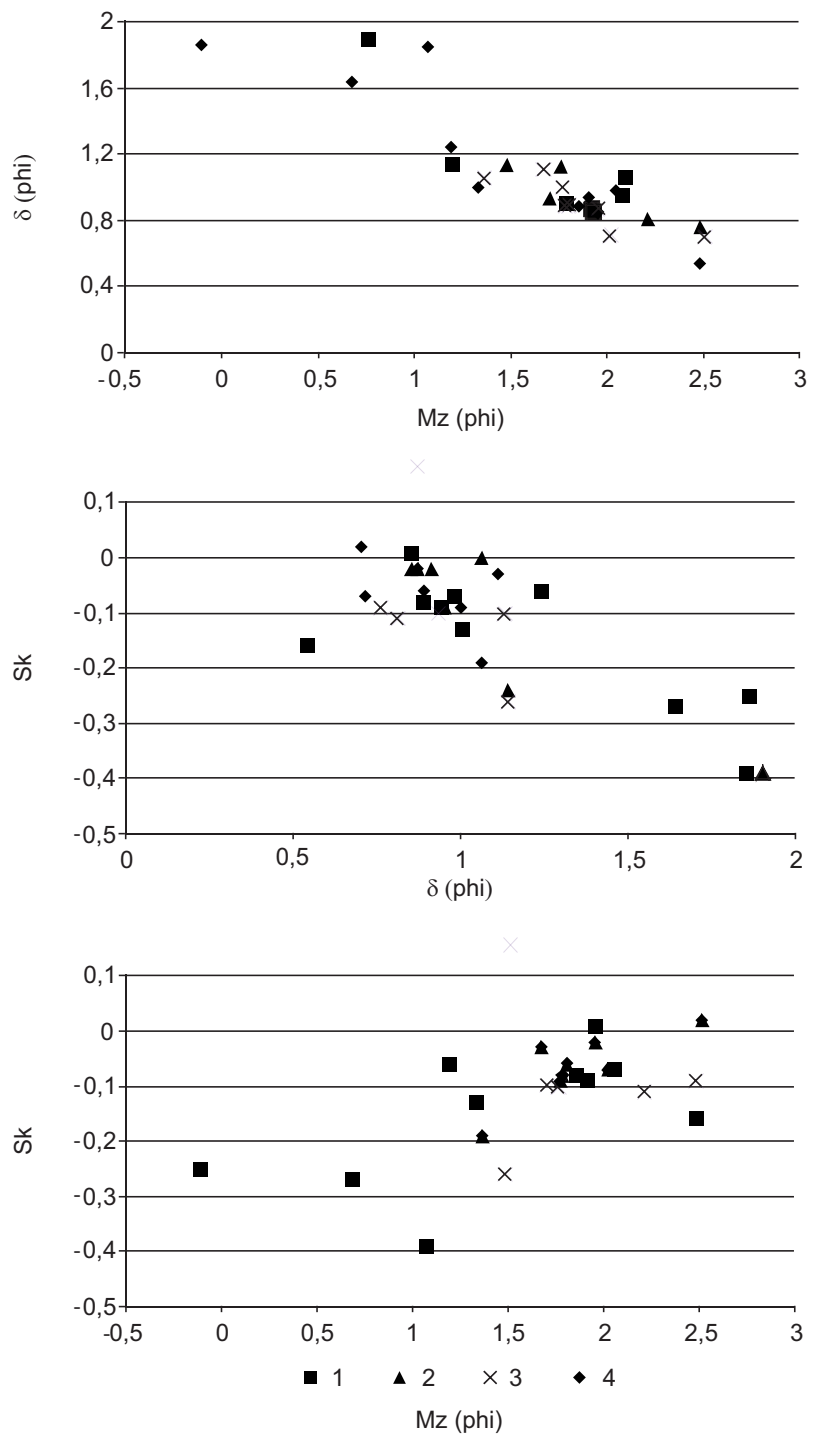

Ryc. 5. Związki pomiędzy wskaźnikami uziarnienia

A - średnią średnicą ziarna $(\mathrm{Mz})$ a odchyleniem standardowym ( $\delta), \mathrm{B}$ - skośnością (Sk) a odchyleniem standardowym (ठ), C - skośnością (Sk) a średnią średnicą ziarna (Mz)

1 - osady górnej części dolinki $\mathrm{B}, 2$ - osady górnej części dolinki A, 3 - osady dolnej części dolinki A, 4 - osady dolnej części dolinki B

Fig. 5. Relationships between grain-size distribution indexes $\mathrm{A}$ - average grain diameter $(\mathrm{Mz})$ and standard deviation $(\delta)$, $\mathrm{B}$ - skewness (Sk) and standard deviation $(\delta), \mathrm{C}-$ skewness (Sk) and average grain diameter $(\mathrm{Mz})$

1 - deposits of upper part of valley B, 2 - deposits of upper part of valley A, 3 - deposits of lower part of valley A, 4 - deposits of lower part of valley $B$

towane są jako proluwia. Linijny odpływ wód doprowadził do segregowania materiału. Drobne ziarna zostały wymyte i odprowadzone z osadu. Analiza zawartości węglanu wapnia $\mathrm{CaCO}_{3}$ w osadzie pozwala na stwierdzenie nieznacznego wzrostu jego zawartości w piaskach gruboziarnistych. Generalnie zawartość $\mathrm{CaCO}_{3}$ jest niewielka i wynosi od 0,5 do 3,4 \%. Stopień obróbki ziarna kwarcowego wykazuje znaczny udział ziaren o pośrednim typie obróbki - $\beta$, powyżej $65 \%$ dla frakcji $1,0-1,8 \mathrm{~mm}$ i powyżej $70 \%$ dla frakcji $1,0-1,4 \mathrm{~mm}$.
W celu analizy cech środowiska sedymentacyjnego badanych osadów zastosowano wykresy wzajemnych zależności pomiędzy wyliczonymi wskaźnikami uziarnienia $\mathrm{Mz}-\delta, \mathrm{Sk}-\delta, \mathrm{Sk}-\mathrm{Mz}$ (Folk, Ward 1957, ryc. 5). Porównanie wartości średniej średnicy ziarna $(\mathrm{Mz})$ z odchyleniem standardowym $(\delta)$ pozwala stwierdzić, że im drobniejsze ziarno, tym lepiej wysortowane. Jest to układ charakterystyczny dla środowisk o zróżnicowanej dynamice i dużej zmienności siły transportującej osad, szczególnie dla osadów fluwialnych facji korytowych (m.in. Mycielska-Dowgiałło 1992). Układ taki rozpoznany został m.in. przez Twardego $(2000,2003)$ w neoholoceńskich osadach stokowych $\mathrm{w}$ strefie krawędziowej Wyżyny Łódzkiej. Osady autor interpretuje jako proluwia, do których zalicza osady nadbudowujące dna wąwozów i parowów, stożki u ich wylotów oraz osady w dnach dolin denudacyjnych poniżej ujść parowów. Ponadto zaobserwowano, że im drobniejszy materiał, tym większa wartość skośności. Generalnie osady cechują się ujemnymi wartościami skośności (Sk), co wskazuje na wyraźnie przepływowy charakter środowiska sedymentacyjnego (Mycielska-Dowgiałło 1992).

W celu określenia dynamiki środowiska depozycyjnego zastosowano analizę krzywych kumulacyjnych i krzywych częstości osadu. Analiza przebiegu krzywych kumulacyjnych osadów budujących dno dolnej i górnej części dolinek wskazuje na pewne różnice $\mathrm{w}$ ich kształcie. Bardziej poziomy przebieg krzywych zaobserwowano w odniesieniu do odcinków ujściowych dolinek dla próbek 3 i 5 (ryc. 6). Reprezentują one piaski średnioziarniste ze znaczną domieszką frakcji gruboziarnistych (do 10\%) i żwirów $(0,8-4 \%)$ (próbka nr 3, stanowisko A; ryc. 3,6$)$. Dla osadów górnych części dolinek nie widać tak wyraźnie zaznaczającej się zmienności w przebiegu krzywych. Generalnie odnotowuje się zarówno dla dolnych, jak i górnych odcinków dolinek słabsze wykształcenie części górnej krzywej, co zgodnie z analizą Vishera (1969) wskazuje na niewielki udział transportu ziarna w postaci zawiesiny lub transportu eolicznego. Zawiesina stanowiła do kilku procent ładunku osadu transportowanego. Na podstawie analizy krzywych częstości zaobserwowano, że główne mody odpowiadają przedziałom frakcji 0,5 phi i 3 phi (ryc. 7). W osadach ujściowych dolinek zaobserwowano zwiększenie wartości częstości (do 15) występowania frakcji w przedziale od -3 do -2 phi. Pokrywy deluwialne wykształcone na wschodnim zboczu Buślarskich Gór utworzone są w głównej mierze przez masywny piasek średnio- i drobnoziarnisty. Uformowane one zostały w postaci pokryw o nieznacznej miąższości (maksymalnie do $0,7 \mathrm{~m}$ ), o słabym stopniu wysortowania.

\section{Dyskusja}

Zróżnicowany stopień wysortowania odzwierciedlony jest w przebiegu krzywych częstości i wskazuje na pulsacyjny charakter przepływu o zmiennej dynamice śro- 
A I
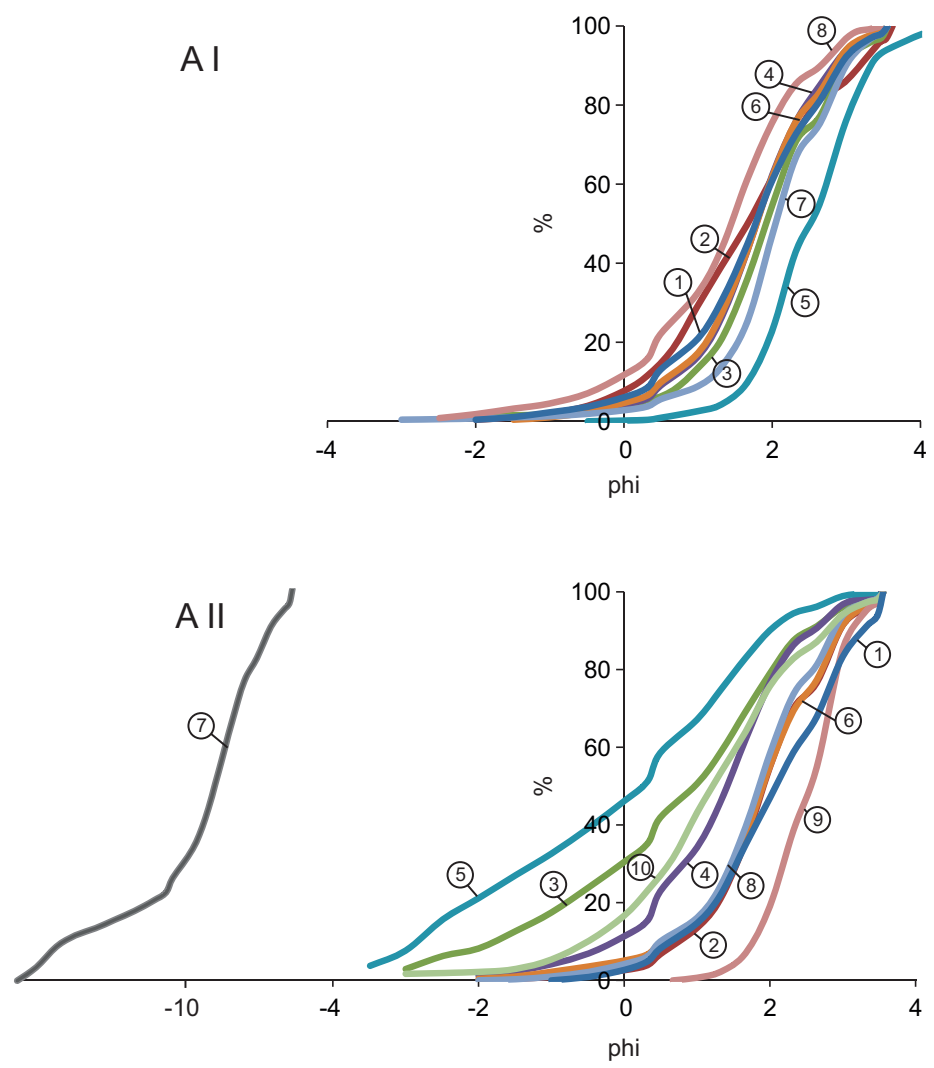

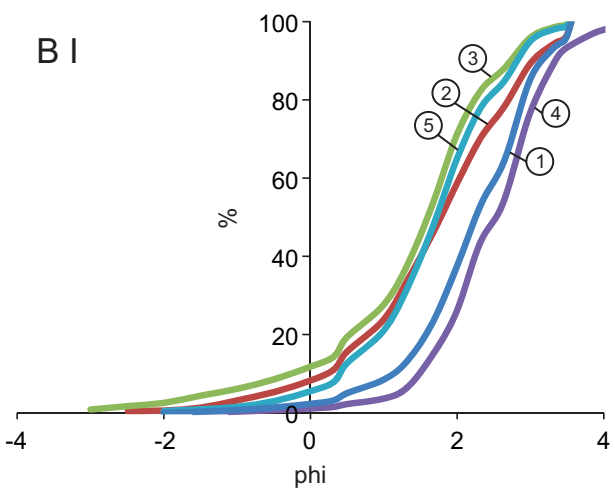

(1) -1
B II

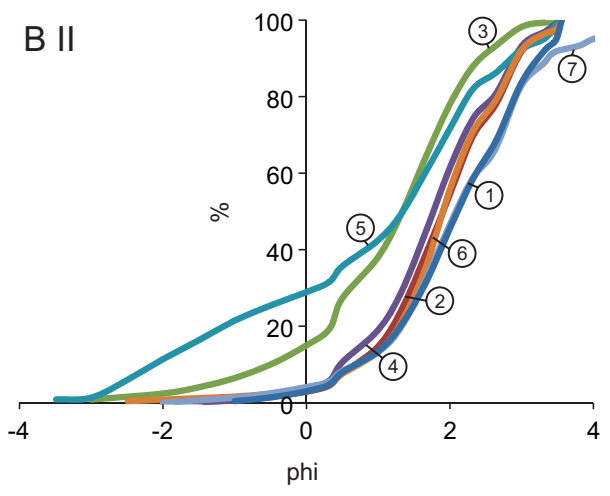

Ryc. 6. Krzywe kumulacyjne osadów dolinek A i B

A I - osady górnej części dolinki A, A II - osady dolnej części dolinki A, B I - osady górnej części dolinki B, B II - osady dolnej części dolinki B, 1 - numery prób

Fig. 6. Cumulative curves for deposit samples from valleys A and B

A I - deposits of upper part of valley A, A I - deposits of lower part of valley A, B I - deposits of upper part of valley B, B II - deposits of lower part of valley B, 1 - sample numbers

dowiska akumulującego osad. Ponadto zauważono, że mody przypadają kolejno na coraz drobniejsze frakcje, co wskazuje na selektywną depozycję materiału (ryc. 7). Analizując przebieg krzywych częstości, zauważa się występowanie kilku mód (ryc. 7). Jest to charakterystyczne dla deluwiów i obserwowane było m.in. przez Twardego (2002, 2003) czy Smolską (2005).

Słaby stopień wysortowania osadów wskazywać może na nieznaczną odległość transportowanego osadu. Ponadto niewielka miąższość pokryw deluwialnych może oznaczać, że na badanym obszarze skala procesów denudacyjnych była nieduża w porównaniu ze skalą tych procesów na obszarach peryglacjalnych, bądź, co wydaje się bardziej prawdopodobne, krótka droga transportu osadu nie sprzyjała tworzeniu miąższych pokryw deluwialnych. Większość materiału musiała być odtransportowana i włączona w system fluwialny rzeki Dębnicy.

Za jeden z głównych procesów inicjujących powstanie dolinek erozyjno-denudacyjnych uznać należy działalność wód spływających po powierzchni terenu, przypuszczalnie po podłożu zmarzliny. W strefie peryglacjalnej zlodowacenia wisły panowały najkorzystniejsze warunki do spełzywania i spłukiwania oraz do powstania miąższych pokryw deluwialnych (Stochlak 1978). Ciągła wieloletnia zmarzlina utworzyła się wyłącznie na południe od zasięgu fazy pomorskiej i istniała do końca najstarszego dryasu, podczas gdy na północ od zasięgu tej fazy, a zatem na obszarze badań, mogła istnieć jedynie nieciągła wieloletnia zmarzlina (Kozarski 1995). Można przypuszczać, że po najstarszym dryasie na terenie Polski północnej zachowały się jedynie izolowane płaty wieloletniej zmarzliny. Jak podaje Ralska-Jasiewiczowa (1999), średnia temperatura lipca w allerödzie wynosiła już $14-15^{\circ}$. Zanik wieloletniej zmarzliny miał miejsce podczas bölling-allerödu (Liedtke 1993, Böse 1995, Marks 1996) bądź w preborealu (Gołębiewski 1981, Florek 1991, Błaszkiewicz 2005, 2011, van Loon $\mathrm{i}$ in. 2012). W trakcie depozycji ważną rolę odgrywały także procesy wietrzenia mrozowego. Wskazuje na to znaczny udział w osadach ziaren typu $\beta$.

Procesy erozji z kolei odpowiedzialne są za wyprzątnięcie materiału poza dno dolinki (m.in. Majewski 2002, Paluszkiewicz 2009, Tylman 2011). Procesy spłukiwania doprowadziły do segregacji materiału, frakcje drobnoziarniste zostały wymyte i odprowadzone z osadu.

Różnice w wysokości pomiędzy górną a dolną częścią stoku, który już w późnym glacjale stanowił predyspozycję do rozwoju form dolinek erozyjno-denudacyjnych sprzyjały organizowaniu się spływu powierzchniowego na stoku i jego rozcinaniu (Paluszkiewicz 2011). Analizowane osady deluwialne będące efektem działania procesów denudacyjnych, głównie procesu spłukiwania, zarówno pod względem wykształcenia cech struktural- 
A I
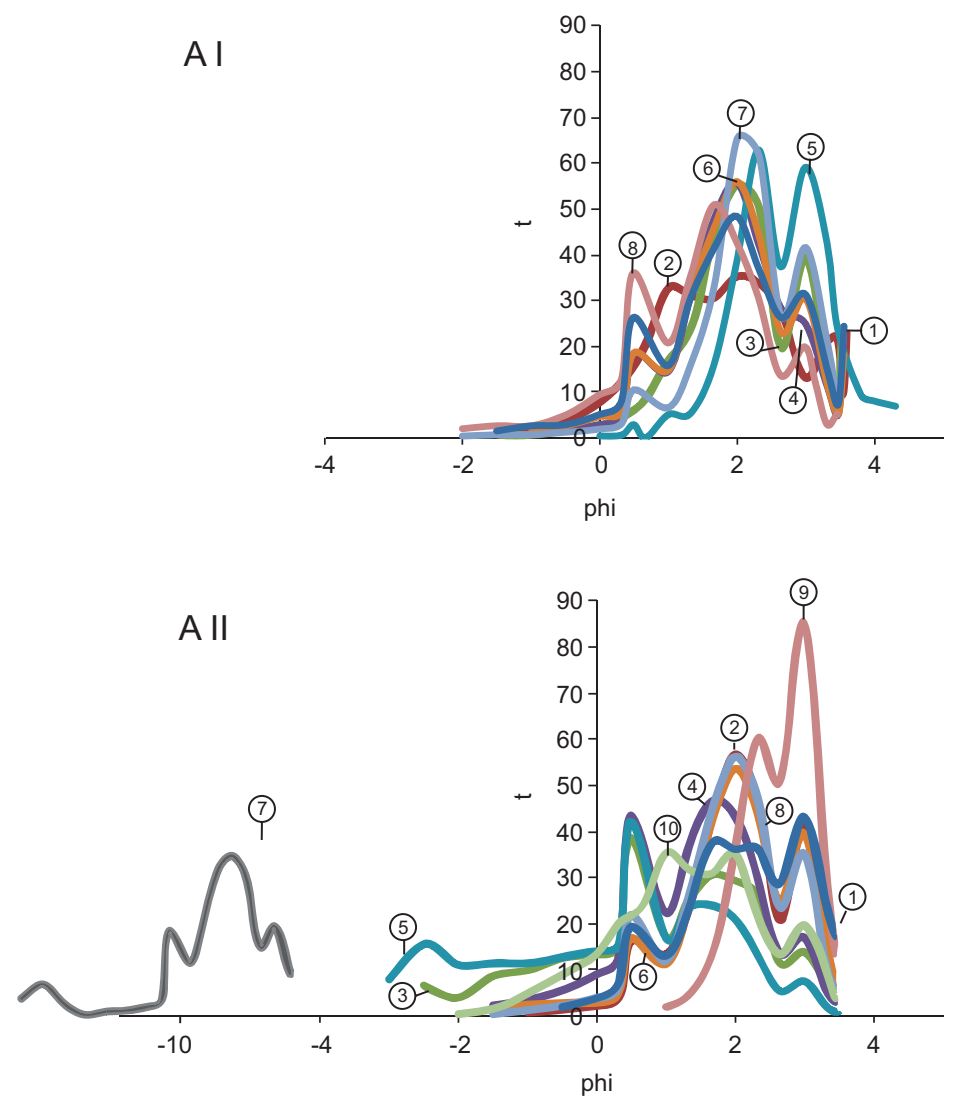
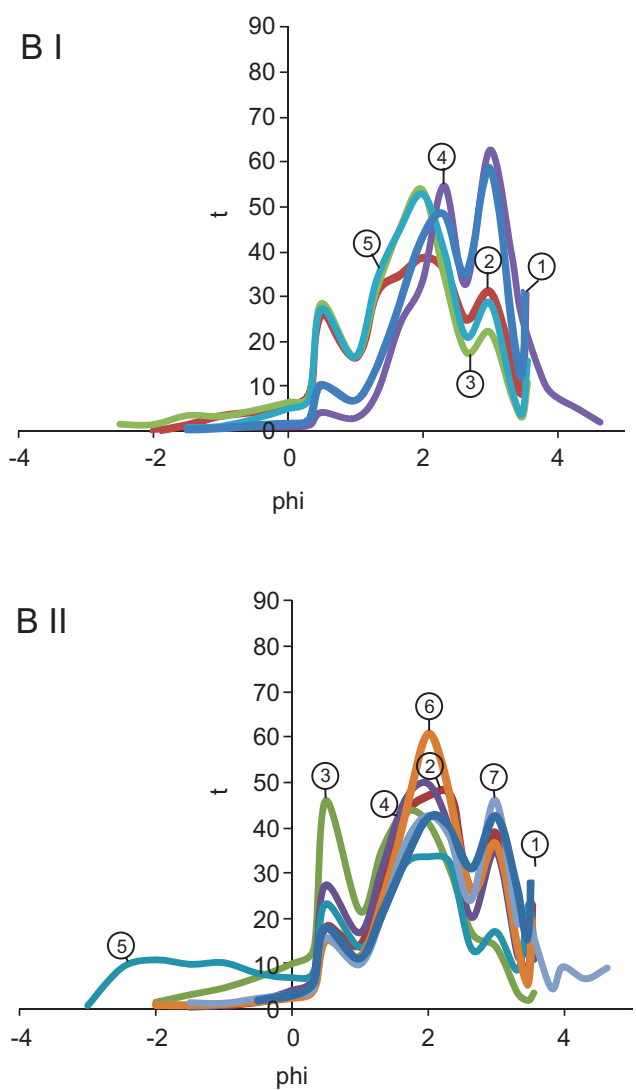

Ryc. 7. Krzywe częstości osadów dolinek A i B. Objaśnienia jak na rycinie 6

Fig. 7. Frequency curves for deposit samples from valleys A and B. Symbols as in Fig. 6

nych, jak i teksturalnych są porównywalne z osadami deluwialnymi badanymi m.in. przez Smolską na Pojezierzu Suwalskim (Smolska 2005) czy Twardego na Wyżynie Łódzkiej (Twardy 2000, 2003). Generalnie na wykształcenie badanych przez autorkę osadów miały wpływ warunki w skali regionalnej (położenie w strefie marginalnej zlodowacenia wisły, znaczne deniwelacje terenu jak na obszary nizinne) i lokalnej (niewielka długość dolinek erozyjno-denudacyjnych, małe powierzchnie zlewni dolinek). Z pewnością nieznaczne głębokości wcięcia dolinek obok uwarunkowań geomorfologicznych, a przede wszystkim budowy geologicznej obszaru świadczą o niewielkiej intensywności procesów denudacyjnych zachodzących na badanym terenie.

\section{Podsumowanie}

W okresie od późnego plejstocenu i przez cały holocen powierzchnie silnie nachylone kształtowane były m.in. przez procesy denudacyjne. Ruchy masowe (głównie spełzywanie) oraz spływy linijne (spłukiwanie) prowadziły do powstania form wklęsłych, m.in. dolinek erozyjno-denudacyjnych. Efektem tych procesów była depozycja osadów deluwialnych reprezentowanych głównie przez piaski różnoziarniste, $\mathrm{z}$ dużym udziałem frakcji pylastej i części próchnicznych.

Wśród czynników, które pełnią istotną rolę w kształtowaniu pokryw stokowych, wymienić należy:
- morfologię terenu (nachylenie, długość, kształt profilu stoku, ekspozycja),

- stopień pokrycia szatą roślinną,

- typ i charakter przebiegu procesów zachodzących na stoku.

Strefa krawędziowa Buślarskich Gór oddziela obszar wysoczyzny falistej od doliny rzeki Dębnicy. Od wierzchowiny wysoczyzny położonej na wysokości $150 \mathrm{~m}$ n.p.m. teren opada w pasie o szerokości 0,7 do $1,2 \mathrm{~km}$ do wysokości 80 m n.p.m. w dolinę rzeki Dębnicy. Stok, w którego obrębie zinwentaryzowano dolinki erozyjno-denudacyjne ma profil wypukło-wklęsły.

W analizowanych przypadkach za główny proces kształtujący dolinki uznać należy spłukiwanie, którego intensywność współcześnie w znacznej mierze warunkowana jest gospodarczą działalnością człowieka. Obecnie w strefie klimatu umiarkowanego proces ten uznawany jest za efemeryczny, a jego akumulacyjne efekty w postaci osadów deluwialnych są niewielkie (za: Stochlak 1978). W analizowanym przypadku na stoku o deniwelacjach wynoszących $70 \mathrm{~m}$ w pierwszym etapie rozwijał się proces spłukiwania powierzchniowego, którego efektem są niewielkiej miąższości pokrywy deluwialne reprezentowane przez smugowane, słabo wysortowane piaski drobno- i średnioziarniste. Osad ten przykryty został następnie przez masywne serie piasków średnioziarnistych pochodzących również ze spłukiwania. 


\section{Podziękowania}

Autorka dziękuje recenzentom za krytyczne uwagi dotyczące treści artykułu. Praca częściowo finansowana ze środków Ministerstwa i Szkolnictwa Wyższego jako projekt badawczy N N304 274340.

\section{Literatura}

Bednarek R., Dziadowie H., Pokojska U., Prusinkiewicz Z., 2004. Badania ekologiczno-gleboznawcze. Wydawnictwo Naukowe PWN, Warszawa: 344

Blott S.J., Pye K., 2001. Gradistat: a grain size distribution and statistics package for the analysis of unconsolidated sediments. Earth Surface Processes and Modern Environments 26: 1237-1248.

Błaszkiewicz M., 2005. Późnoglacjalna i wczesnoholoceńska ewolucja obniżeń jeziornych na Pojezierzu Kociewskim (wschodnia część Pomorza). Prace Geograficzne Instytutu Geografii Przestrzennego Zagospodarowania PAN: 201

Błaszkiewicz M., 2011. Timing of the final disappearance of permafrost in the central European Lowland, as reconstructed from the evolution of lakes in N Poland. Geological Quarterly 55(4): 361-374.

Böse M., 1995. Problems of dead ice and Ground ice in the central part of the North European Plain. Quaternary International 28: 123-125.

Churska Z., 1965. Późnoglacjalne formy denudacyjne na zboczach pradoliny Noteci-Warty i doliny Drwęcy. Studia Societatis Scientiarum Torunensis 6(1): 112 .

Dobracka E., 2009. Objaśnienia do szczegółowej mapy geologicznej Polski w skali 1:50 000. Arkusz Połczyn Zdrój (158).

Dzięciołowski W. (red.), 1980. Ćwiczenia z gleboznastwa. Wydawnictwo Akademii Rolniczej Poznań: 305.

Florek W., 1991. Postglacjalny rozwój dolin rzek środkowej części północnego skłonu Pomorza. WSP, Słupsk: 238.

Folk R.L., Ward W.C., 1957. Brazos river bar: a study of the significance of grain size parameters. Journal of Sedimentary Petrology 27(1): $3-26$.

Gołębiewski R., 1981. Kierunki i intensywność denudacji na obszarze zlewni Raduni w późnym würmie i holocenie. Zeszyty Naukowe Uniwersytetu Gdańskiego, Rozprawy i Monografie 26.

Instrukcja opracowania i wydania szczegółowej mapy geologicznej Polski w skali 1:50 000 - zbiór wymagań formalnych i merytorycznych dotyczących sporządzania tego typu mapy, 2004. PIG, Warszawa: 127.

Jersak J., Śnieszko Z., 1987. Zmiany środowiska geograficznego w późnym vistulianie i holocenie na obszarach lessowych Wyżyny Miechowskiej i Opatowsko-Sandomierskiej. Wybrane zagadnienia paleogeografii czwartorzędu - holocen. Prace Naukowe UŚ 712: 7-24.

Klatkowa H., 1965. Niecki i doliny denudacyjne w okolicach Łodzi. Acta Geographica Lodziensia 19, Łódź: 142.

Kołodyńska-Gawrysiak R., 2004. Ponadregionalne i lokalne uwarunkowania holoceńskiego rozwoju suchych dolin Wyżyny Lubelskiej. W: A. Kostrzewski (red.), Geneza, litologia i stratygrafia utworów czwartorzędowych. IV. Seria Geografia 68: 197-210.

Kondracki J., 1998. Geografia regionalna Polski. Wyd. Nauk. PWN, Warszawa: 440

Kostrzewski A., 1971. Niecki denudacyjne w krawędzi wysokiej terasy ujściowego odcinka doliny Bobru. Badania Fizjograficzne nad Polska Zachodnią XXIV(A), Geografia Fizyczna: 77-95.

Kozarski S., 1971. Ślady działalności późnowürmskich procesów peryglacjalnych w regionie dolnej Odry i dolnej Warty. Badania Fizjograficzne nad Polską Zachodnią XXIV(A), Geografia Fizyczna: 97-197.

Kozarski S., 1995. Deglacjacja północno-zachodniej Polski: warunki środowiska i transformacja geosystemu ( $20 \mathrm{ka} \rightarrow 10 \mathrm{ka} \mathrm{BP})$. IGiPZ PAN, Dokumentacja Geograficzna 1.

Krygowski B., 1964. Graniformametria mechaniczna, teoria, zastosowanie. PTPN, Prace Komisji Geograficzno-Geologicznej, 2(4).
Liedtke H., 1993. Phasen periglaziär-geomorphologischer Prägung während der Weichseleiszeit im norddeutschen Tiefland. Zeitschrift für Geomorphologie 93: 69-94.

Majewski M., 2002. Morfogeneza dolinek erozyjno-denudacyjnych w rynnie jeziora Jasień u schyłku plejstocenu i holocenu. W: K. Klimek, K. Kocel (red.), Transformacja dolin plejstoceńskich w holocenie. Strefowość i piętrowość zjawisk, Sosnowiec: 71-73.

Majewski M., 2008. Ewolucja form i osadów w późnym vistulianie i holocenie w rynnie jeziora Jasień. Landform Analysis 7: 95-101.

Marks L., 1996. Role of buried dead ice in modeling of lake basins in present lakelands. Acta Geographica Lodziensis 71: 181-193.

Mazurek M., Paluszkiewicz R., 2013. Formation and development of a 1st-order valley network in postglacial areas (the Dębnica catchment). Landform Analysis 22: 75-87.

Miall A.D., 1977. A review of the braided-river depositional environment. Earth-Science Reviews 13: 1-61.

Mycielska-Dowgiałło E., 1992. Wybrane cechy tekstualne osadów i ich wartość interpretacyjna. W: E. Mycielska-Dowgiałło, A. Muszyńska-Pękalska (red.), Badania sedymentologiczne osadów czwartorzędowych. Komisja Litologii i Genezy Osadów Czwartorzędowych Komitetu Badań Czwartorzędu PAN, Wydział Geografii i Studiów Regionalnych UW: 30-141.

Paluszkiewicz R., 2008. Charakterystyka osadów stożka napływowego suchej dolinki erozyjno-akumulacyjnej Piaski Pomorskie (Pomorze Zachodnie). Landform Analysis 9: 68-71.

Paluszkiewicz R., 2009. Zróżnicowanie litologiczne osadów dolinek erozyjno-denudacyjnych (Pomorze Zachodnie). W: A. Kostrzewski, R. Paluszkiewicz (red.), Geneza, litologia i stratygrafia utworów czwartorzędowych. V. Seria Geografia 88: 383-406.

Paluszkiewicz R., 2011. Erosional-denudational valleys and their significance for the reconstruction of the late glacial environmental conditions (the Drawsko Lakeland, NW Poland). Quaestiones Geographicae 30(3): 71-81.

Racinowski R., 1973. Analiza uziarnienia. W: E. Rühle (red.), Metodyka badań osadów czwartorzędowych. Wydawnictwo Geologiczne, Warszawa: 331-335.

Ralska-Jasiewiczowa M., 1999. Ewolucja szaty roślinnej. W: L. Starkel (red.), Geografia Polski. Środowisko przyrodnicze. PWN, Warszawa: 105-127.

Rotnicki K., 1966. Rzeźba Wzgórz Ostrzeszowskich jako rezultat rozwoju stoku podczas würmu. PTPN, Wydział Matematyczno-Przyrodniczy, Prace Komisji Geograficzno-Geologicznej V(2): 260.

Smolska E., 2005. Znaczenie spłukiwania w modelowaniu stoków młodoglacjalnych (na przykładzie Pojezierza Suwalskiego). WGiSR, Uniwersytet Warszawski, Warszawa: 146.

Stochlak J., 1978. Struktury i tekstury młodoplejstoceńskich osadów deluwialnych. Biuletyn Instytutu Geologicznego 306, XXI: 115-161.

Teisseyre A.K., 1994. Spływ stokowy i współczesne osady deluwialne w lessowym rejonie Henrykowa na Dolnym Śląsku. Prace Geologiczno-Mineralogiczne 43: 178.

Twardy J., 2000. Deluwia neoholoceńskie - przykłady z Wyżyny Łódzkiej. Acta Geographica Lodziensia 78: 135-203.

Twardy J., 2003. Cechy sedymentologiczne neoholoceńskich osadów stokowych na Wyżynie Łódzkiej i ich wartość interpretacyjna. Prace i Studia Geograficzne WGiSR UW 33: 25-44.

Tylman I., 2011. Morfogeneza dolinki denudacyjno-erozyjnej koło Maziowa (dolina Wieprzy). Słupskie Prace Geograficzne 8: 109-128.

Van Loon A.J., Błaszkiewicz M., Degórski M., 2012. The role of permafrost shaping the Late Glacial relief of northern Poland. Netherlands Journal of Geosciences - Geologie en Mijnbouw 91-1/2: 223-231.

Visher G.S., 1969. Grain size distribution and depositional processes. Journal of Sedimentary Petrology 39: 1074-1106.

Zieliński T., 1995. Kod litofacjalny i litogenetyczny - konstrukcja i zastosowanie. W: E. Mycielska-Dowgiałło, J. Rutkowski (red.), Badania osadów czwartorzędowych. Uniwersytet Warszawski, Warszawa: 220-235.

Zieliński T., Pisarska-Jamroży M., 2012. Jakie cechy litologiczne osadów warto kodować, a jakie nie? Przegląd Geologiczny 60(7): 387397. 